\title{
Repeated debris avalanches on Tenerife and genesis of Las Cañadas caldera wall (Canary Islands)
}

\author{
Jean M. Cantagrel \\ Nicolas O. Arnaud \\ Département Sciences de la Terre, Université B. Pascal, 5 rue Kessler, 63000, Clermont-Ferrand, France \\ Eumenio Ancochea \\ José M. Fúster \\ María J. Huertas \\ Departamento de Petrología y Geoquímica, Facultad Ciencias Geológicas, Universidad Complutense, 28040 Madrid, Spain
}

\begin{abstract}
Geologic evidence on Tenerife, Canary Islands, indicates six successive north-directed debris avalanche events, including: the Anaga and Teno (ca. $6 \mathrm{Ma}$ ) events that affected the old basaltic series, and the Tigaiga (>2.3 Ma), Roques de García (possibly 0.6-0.7 Ma), Orotava (ca. 0.6 Ma), and Icod (<0.15 Ma) avalanche events that affected the Cañadas and Dorsal volcanic edifices. The approximate total volume $\left(>1000 \mathrm{~km}^{3}\right)$ inferred for these events can account for the volume of previous estimates of offshore volcanic debris. These repeated flank failures can also account for the present morphology of Las Cañadas caldera wall, which partly bounds a multiepisodic lateral-collapse structure $25 \mathrm{~km}$ wide.
\end{abstract}

\section{INTRODUCTION}

The Cañadas volcanic edifice of Tenerife, Canary Islands, grew upon the 8-3.2 Ma old basaltic series comprising the Teno, Anaga, and Roque del Conde massifs (Fig. 1 A). It is currently indented by the Las Cañadas caldera, a semielliptical depression having a northeasttrending axis $16 \mathrm{~km}$ long and a southeastern wall as high as $\mathbf{5 0 0} \mathrm{m}$. The origin of the Cañadas caldera has long been debated. In the recent years the debate has focused on the alternatives of vertical collapse versus lateral collapse, or a combination of both. We recognize that deposits of both ignimbrites and debris avalanches exist both on land and offshore of Tenerife. In this paper we focus on the avalanches, differentiating several successive events that we interpret as repeated lateral collapses of the Cañadas edifice and that can explain the scalloped horseshoe trace of the caldera wall. The hypothesis of lateral collapse was first expressed by Navarro and Coello (1989), and the recent discovery of more than

Figure 1. A: Main volcanic structures of Tenerife Island. CE, Las Cañadas edifice; CC, Las Cañadas caldera; T, Teide; DE, Dorsal edifice; I-I', cross section of Figure 3. B: Sketch map of Las Cañadas lateral-collapse structure; contours drawn from satellite Spot image; ages in Ma. VC-1 and VC-2, inferred position of verticalcollapse calderas; $C_{2}$ and $C_{3}$, inferred centers for Cañadas II and Cañadas III phase edifices. Curves 1, 2, and 3 are traces of successive avalanche rim faults: Tigaiga, Icod, and Roques de García respectively; arrows indicate directions of the avalanches.

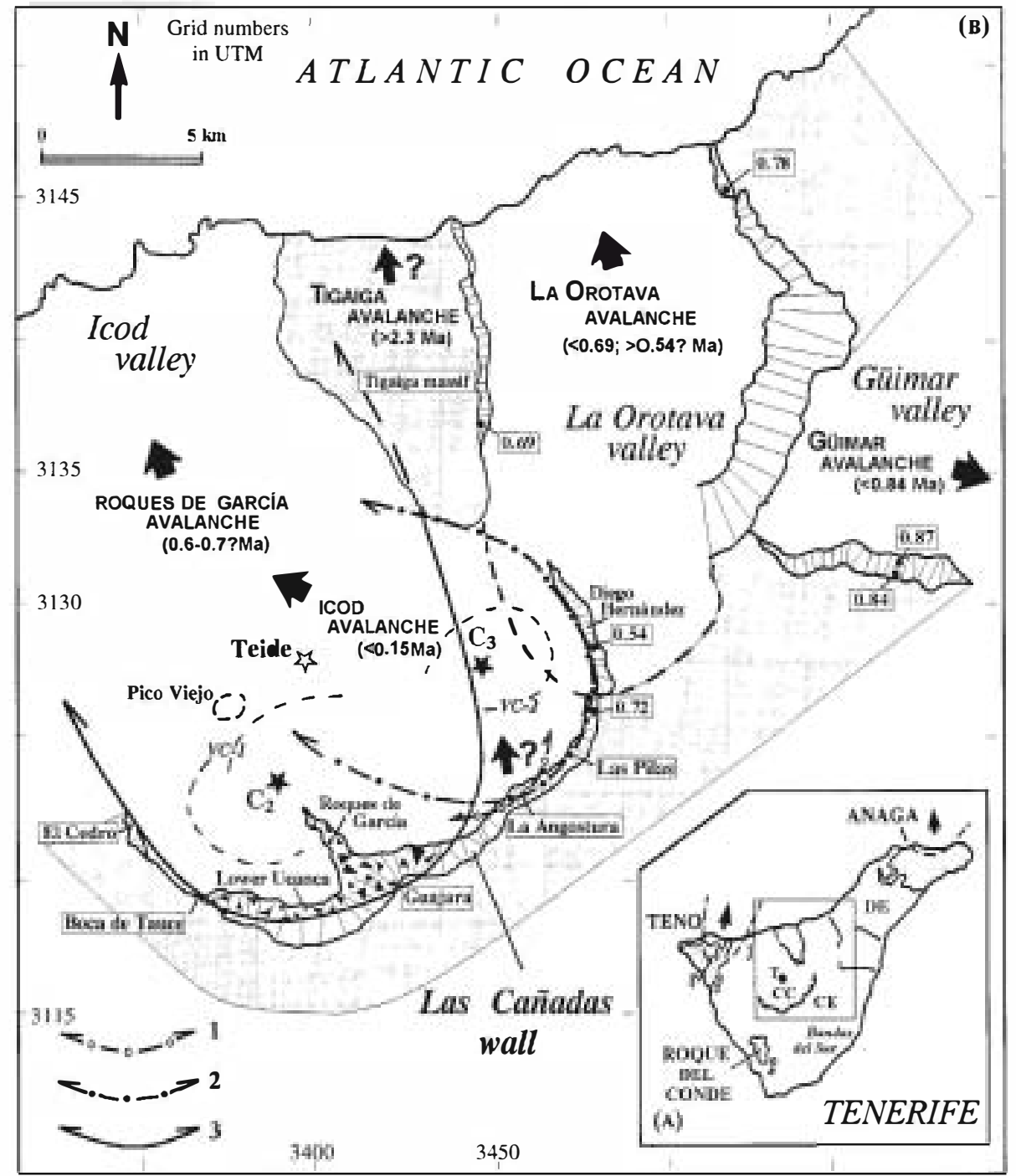


$1000 \mathrm{~km}^{3}$ of volcanic debris spread widely across the sea floor north of Tenerife is a strong argument in favor of the hypothesis (Watts and Masson, 1995). Subaerial evidence also supports this origin for the Las Cañadas caldera.

\section{VOLCANIC STRATIGRAPHY AND CHRONOLOGY OF LAS CAÑADAS EDIFICE}

Las Cañadas edifice was built by a long complex series of eruptions during the past 3.5 m.y. Figure 2 presents a simplified sequence based on geologic mapping, radiometric dating, and other observations (Ancochea et al., 1999). Las Cañadas grew in three main phases. The Cañadas I phase (C-I phase), between 3.5 and 2.6 Ma, was essentially basaltic but included a few late salic eruptions. Basaltic flows dated as 3 Ma crop out low in the caldera wall at Boca de Tauce and $\mathrm{La}$ Angostura (Fig. 1B) and in the deepest ravines along the southern flank of the Cañadas edifice. To the north flank, at the base of the Tigaiga massif (Fig. 1B), is the Tigaiga breccia described by Bravo (1962) and interpreted as a landslide deposit by Navarro and Coello(1989). This breccia is $200-300 \mathrm{~m}$ thick but is visible only in water tunnels. It consists of fragmented volcanic material within a clay-rich matrix; it is overlain by 2.3 Ma trachybasaltic flows (Ibarrola et al., 1993). The Tigaiga breccia is inferred to mark the end of the C-I phase of growth.

The Cañadas II phase (C-II phase), produced a lower (2.3-2.0 Ma) sequence of trachybasalt flows and an upper sequence of southwest-dipping phonolites that crop out in the caldera wall at El Cedro (Fig. 1B). On the upper south flank of the Cañadas edifice are intermediate to salic flows
(2.3-2.2 Ma), overlain by a thick basaltic succession (1.9 Ma) and then south-dipping phonolites (upper Ucanca unit, 1.5-1.4 Ma). Several welded and nonwelded pyroclastic flows of the C-II phase (Fúster et al., 1994) that have $\mathrm{Ar} / \mathrm{Ar}$ ages between 1.8 and 1.5 Ma (Fig. 2) are well exposed in the southwest slopes of the island. Some of these pyroclastic episodes represent rapid eruptions of several square kilometers or ten of cubic kilometers and therefore probably represent a multiepisodic vertical collapse caldera (VC-1, Fig. 1B) much older than previously recognized (Martí et al., 1994, 1997) on top of the C-II phase edifice. Dikes attributed to the $\mathrm{C}$-II phase edifice radiate from a locus (C2, Fig. 1B) that we infer to approximate the center of the $\mathrm{C}$-II phase edifice. Morphologic reconstruction (Ancochea et al., 1999) suggests that the C-II phase central edifice could have had a basal radius of about $20 \mathrm{~km}$ and reached an elevation of $3200 \mathrm{~m}$. A vertical-collapse caldera related to the ignimbrites must have been located in the vicinity of C2 (VC-1, Fig. 1B), but its size, shape, and exact location are uncertain.

The Cañadas III phase (C-IIIa phase) began ca. 1.1 Ma with basaltic lava flows followed by thick phonolic flows that are now exposed in the Tigaiga massif and also compose the Las Pilas unit in the caldera wall(Fig. 1B). The Dorsal edifice (Ancochea et al., 1999), a northest-trending volcanic ridge, the westernmost flows of which are interbedded with salic rocks from the C-III phase central edifice, was built during the same time. Additional pyroclastic flows (Las Américas ignimbrites, Fig. 2) exposed near the south coast are dated as 0.9-1.0 Ma (Fúster et al., 1994). The upper level of the caldera wall is characterized by several 10-m-thick welded and nonwelded near-

Figure 2. Simplified volcanic stratigraphy, avalanche episodes, and main pyroclastic units of Las Cañadas edifice.

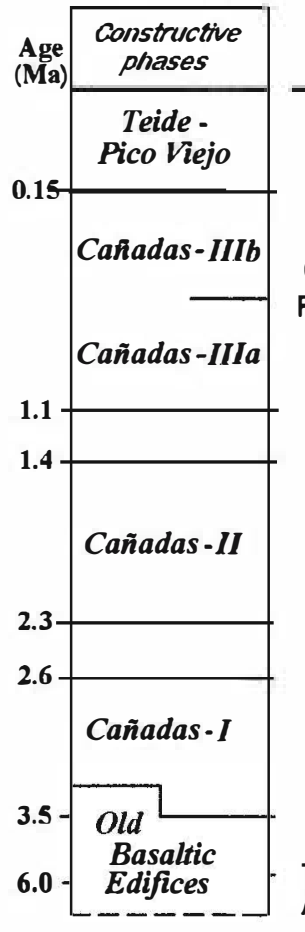

vent phonolitic fall deposits that erupted ca. 0.9 and 0.6 Ma (e.g., at Guajara peak). The final activity of the C-III phase (C-IIIb) edifice (Fig. 2) was dominated by a complex succession of phonolitic pyroclastic eruptions that were studied by Martí et al. (1990) in the easternmost Diego Hernández section of the caldera wall and by Wolff (1985), Alonso (1989), and Bryan et al. (1998) in the Bandas del Sur (Fig. 1B). K/Ar and $\mathrm{Ar} / \mathrm{Ar}$ ages for this late pyroclastic series are between 0.6 Ma (Arico welded ignimbrite) and $\mathbf{0 . 1 3}$ or $0.17 \mathrm{Ma}$ (El Abrigo ignimbrite) and are from rocks exposed on top of the Diego Hernández segment of the caldera wall (Ancochea et al., 1990; Mitjavila and Villa, 1993). Here those pyroclastic deposits are sufficiently voluminous (Bryan et al., 1998) that their eruption probably produced a new complex, vertical-collapse caldera of uncertain size and shape, centered in the vicinity of C3 (VC-2, Fig. 1B).

\section{DEBRIS-AVALANCHE EPISODES}

Teno and Anaga Avalanches of the Old Basaltic Edifices

Watts and Masson (1995) used sonar backscatter to differentiate four debris units on the sea floor north of Tenerife. The oldest units probably correlate with flank failures in the old basaltic massif of Teno and Anaga. Age information is currently not available for the Anaga avalanche, which is likely a pre-Cañadas event. In Teno, however, between an older (6.3-6.7 Ma) westdipping pile and a younger (5.6-5.0 Ma) horizontal pile (Ancochea et al., 1990), is a breccia overlain by volcanic debris flows, each 1-2 m thick. This sequence probably represents the subaerial remains of the Teno avalanche, which therefore must have an age of ca. $6 \mathrm{Ma}$ (Fig. 3).

\section{Tigaiga Avalanche}

Few clues exist for reconstructing the shape of the C-I phase volcano. Assuming that it was a more or less circular basaltic shield, it could have had a radius of $\sim 19 \mathrm{~km}$ and height of $\sim 3000 \mathrm{~m}$ (Ancochea et al., 1999). Alternatively, assuming that it was built along a two- or three-armed rift system (Carracedo, 1994), it might have resembled the Canary Island of El Hierro (Fúster et al., 1993), which has an avalanche caldera (El Golfo) $15 \mathrm{~km}$ in diameter (Masson, 1996). In this latter case, the C-I phase volcano could have had an old (ca. 2.5 Ma) wide depression open to the north and related to the formation of the Tigaiga breccia overlain by $2.3 \mathrm{Ma}$ trachybasalt flows. The trace of a headwall fault may exist along the present caldera wall at La Angostura (Fig. 1B), separating brecciate younger trachyte (2.6-2.7 Ma) at a lower elevation from older (3 Ma) basalt flows in the cliff above (Ancochea et al., 1999).

\section{Roques de García Avalanche}

In the caldera wall, the lower Ucanca unit

(Fig. 1B) is a complex of lava flows, intrusions,
Teno avalanche Anaga avalanche 


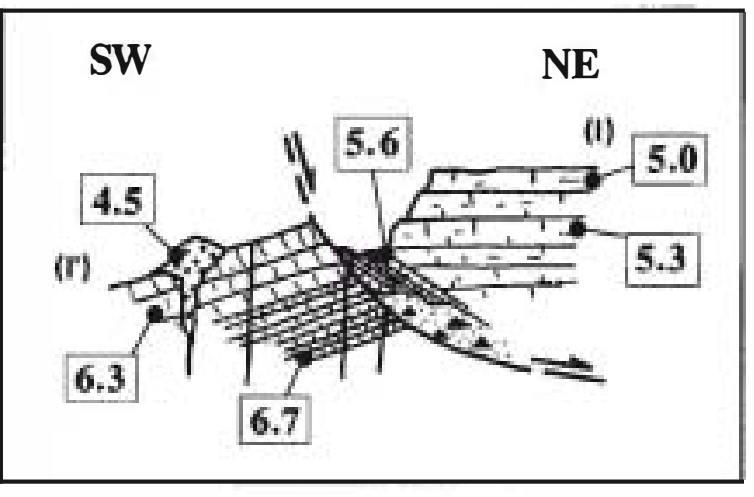

and pyroclastic or polygenic breccias jumbled together with no clear stratigraphy because of the intense fracturing without a preferred trend. It is cut by many dikes having various orientations. The lower Ucanca unit grades across the Cañadas caldera into the Roques de García unit (Fig. 1B). The Roques de García unit is deeply eroded, and its lower levels have a chaotic structure in which blocks of various lithologies and sizes appear to be broken into clasts that can be fit together locally. These shattered blocks are embedded within a more intensively crushed matrix and injected by clastic dikes a few centimeters thick and composed of variously crushed rocks. The lower part of the Roques de García unit has characteristics of a landslide deposit; we interpret it as the proximal facies of a debris-avalanche deposit. In contrast, the upper levels of the Roques de García unit consist of stratified volcaniclastic sediments that are cut locally by later dikes (Fig. 4B).At the foot of the present caldera wall, deep hydrothermal alteration of breccias indicates that the deep interior of the volcanic edifice was involved in an avalanche of great size, not a local rockfall from a preexisting caldera wall.

The age of this avalanche is not well constrained. One phonolitic fragment and one intrusion (or megablock) within the breccia are dated as 1.7 and $1.4 \mathrm{Ma}$ (Fig. 4B), respectively, and one inward-dipping dike (cone sheet or tilted and slided fragment of dike) has been dated as 1.3 Ma. Thus the materials involved in the avalanche are similar in age to the youngest intact rocks of the $\mathrm{C}$-II phase edifice. One dike cutting the undeformed volcaniclastic sedimentary rocks is dated as $0.43 \mathrm{Ma}$, and one radial dike cutting the lower Ucanca unit is dated as $\mathbf{0 . 6}$ Ma. These two sets of ages constrain the age of the Roques de García collapse. Moreover, if the uppermost part of the section at Guajara (Fig. 1B) is cut by the headwall fault of the avalanche caldera, the collapse could have occurred more recently than 0.90 Ma (Ancochea et al., 1995) or even $0.60 \mathrm{Ma}$ (Martí et al., 1997). However, if the uppermost Guajara was not cut by the avalanche, but only later by retreat of the caldera wall, the Roques de García event must have occurred ca. 1.4-1.0 Ma. No more precision is available for this avalanche event because datable synfailure magmatic material has not been identified.

\section{Orotava and Güimar Avalanches}

The Orotava valley is broad (10-12 km wide, opening northward) and steep-walled; a lateral collapse origin is generally accepted. It cuts sharply across the basaltic Dorsal Edifice on its east side and the C-III phase Tigaiga massif on its west side and is floored by a breccia (Coello, 1973). It formed later than $69 \mathrm{Ma}$, the youngest age measured in the C-III phase rocks of the west wall (Tigaiga) and headwall (cutting the Las Pilas unit), but before the oldest fill now exposed (0.54 Ma; Ancochea et al., 1995) in the younger Diego Hernández escarpment (Fig. 1B). The southeast flank of the Dorsal edifice was also marked by another, but south-directed, large landslide that formed the Guiimar valley later than $0.84 \mathrm{Ma}$, as measured on the upper lava flows of its western wall (Ancochea et al., 1990).

\section{Icod Avalanche}

Another north-directed landslide produced the Icod valley (Fig. 1B) ca. $\mathbf{0 . 1 5} \mathrm{Ma}$ (Navarro and Coello, 1989; Ancochea et al., 1990; Watts and Masson, 1995). A subaerial deposit of this landslide is unknown (except in some water tunnels), but can be seen on the sea floor north of Tenerife (Watts and Masson, 1995). For this avalanche, the principal uncertainty is the location of its headwall. Martí et al. (1997) suggested a mechanical connection between a vertical collapse (their Diego Hernández caldera) and the Icod flank collapse, the former triggering the latter. In their interpretation the Icod collapse was limited to the northern flank of the Cañadas edifice. That interpretation has been challenged by Ancochea et al. (1998), and Watts and Masson (1998), who argued that the Icod slide extended southward to the present caldera wall, as proposed by Navarro and Coello (1989) and Watts and Masson (1995). We accept this interpretation, but apply it only to the eastern segment of the caldera wall because we believe that the western segment was formed by the older Roques de García avalanche.

\section{Volume of Avalanche Deposits}

The existence of more than $1000 \mathrm{~km}^{3}$ of debrisavalanche and debris-flow deposits on the sea floor north of Tenerife has been demonstrated

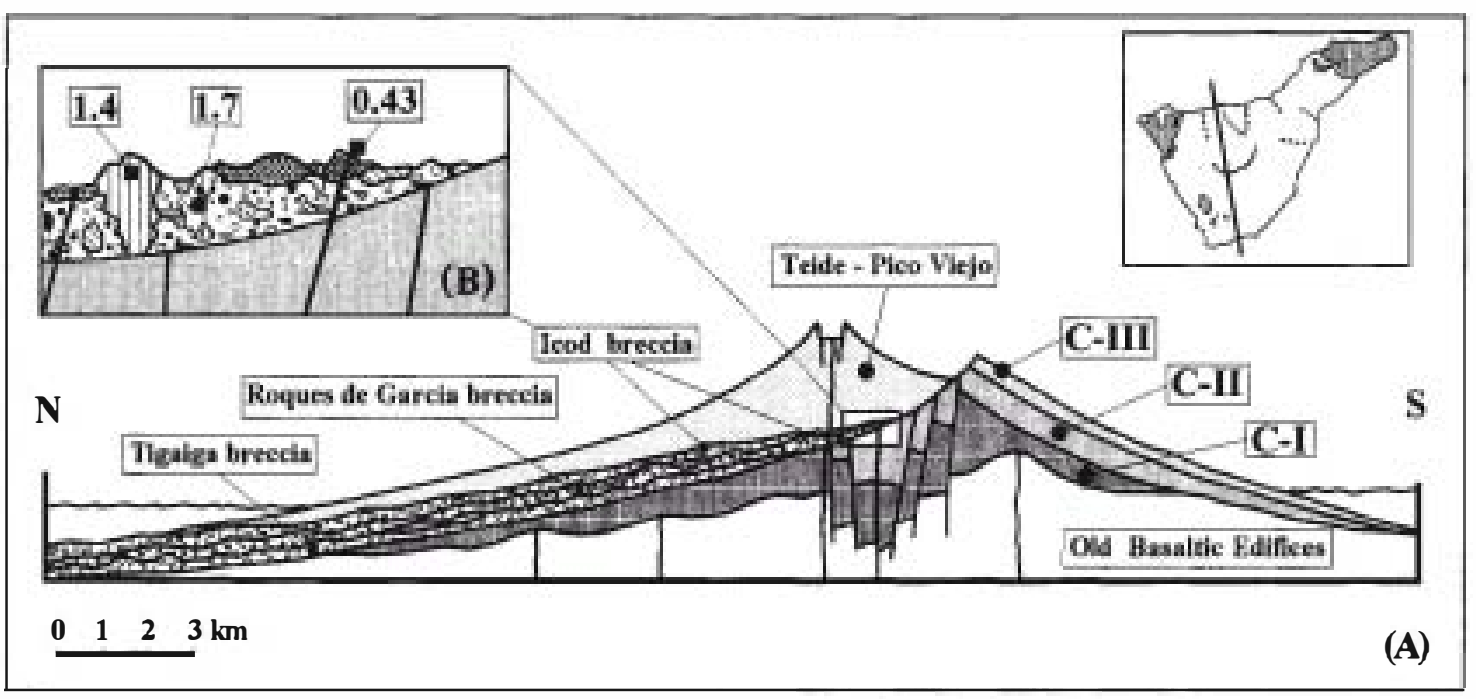

Figure 4. A: Schematic cross section of Tenerife Island; Cañadas I, Cañadas II, and Cañadas III phases are main volcanic units. $B$ : Roques de García debrisavalanche deposit overlain by volcaniclastic sediments cut by dikes. New ages in Ma. 
through marine geophysical studies (Watts and Masson. 1995; Teide Group, 1997). These deposits were formerly atributed to the Icod and Orotava avalanches, but the volume of only these valleys is too small to account for all of the submarine deposits. The volumes of the successive C-I, C-II, and C-III phase edifices can be estmated as about $1000-1200 \mathrm{~km}^{3}$ each. If $20 \%-$ $25 \%$ of each edifice (typical of examples elsewhere; Holcomb and Searle, 1991) was lost in lateral collapses, the total volume lost is about $700-850 \mathrm{~km}^{3}$. However, this does not include material that was lost in forming the Orotava valley, or the unknown volume of the Anaga and Teno landslides; if these are included, and taking into account of volume increase during wansport, there is better agreement between the volume of submarine debris and total subaerial volume lost in the avalanches.

\section{CONCLUSIONS}

The Cañadas edifice was built in three eruptive periods, each ending in large-scale flank collapse. The duration of eruptive periods was nearly 1 m.y. each, enough time to build volcanic cones large enough (Ancochea et al., 1999) to become gravitationally unstable. Several potential caldera-forming pyroclastic eruptions occurred, but the resulting structures are no longer visible. There is geologic evidence on land of six northdirected flank-failure events: theAnaga and Teno (ca. $6 \mathrm{Ma}$ ) events affecting the old basalic series, followed by the Tigaiga (>2.3 Ma), Roques de García (possibly 0.6-0.7 Ma), Orotava (ca. $0.6 \mathrm{Ma}$ ), and the Icod ( $<0.15 \mathrm{Ma}$ ) avalanches affecting the Cañadas and Dorsal edifices. It is possible that other collapses occurred during submarine growth of the Tenerife volcanic complex. This repetition of flank collapse is consistent with what is now known about many other oceanic islands. Canarian examples have been described for El Hierro (Holcomb and Searle, 1991; Fúster et al., 1993) and La Palma Islands (Ancochea et al., 1994). The total volume lost in the avalanches can account roughly for the volume of volcanic debris observed on the sea floor north of Tenerife. Three distinct collapses produced different segments of the Las Cañadas caldera wall, and a fourth produced the Orotava valley. Together they compose a multiepisodic lateralcollapse structure roughly $25 \mathrm{~km}$ wide (Fig. 1B). Since the first of these lateral collapses, the Cañadas edifice probably was very asymmetric (Fig. 4A), the old, clay-rich Tigaiga breccia possibly acting as a weak detachment surface for successive later landslides. In this interpretation. the present shape of the Las Cañadas caldera wall is not related to ignimbritic eruptions and vertical collapse, but is instead a product of repeated flank failures. The western segment of the caldera wall is the legacy of the Roques de García avalanche, and the eastern segment is the result of the younger Icod event.

\section{ACKNOWLEDGMENTS}

This research was supported by Dirección General de Irvestigación Científica y Técrica projects PB940237 and PB96-0572 and by Université B. PascalCentre National de la Recherche Scientifique, Clermont-Ferrand. We thank an anonymous reviewer, and especially R. T. Holcomb for his very careful review and helpful comments.

\section{REFERENCES CITED}

Alonso, J. J., 1989, Estudio volcanoestratigráfico y volcanológico de los piroclastos sálicos del Sur de Tenerife: Col. Irvestigación, Universidad de La Laguna, $257 \mathrm{p}$.

Ancochea, E., Fúster, J. M., Ibarrola, E., Cendrero, A., Coello, J., Hemán, F., Cantagrel, J. M., and Jamnond, C., 1990, Vblcanic evolution of the island of Tenerife (Canary Islands) in the light of new $\mathrm{K}$-Ar data: Joumal of Volcanology and Geothermal Research, v. 44, p. 231-249.

Ancochea, E., Hemán, F., Cendrero, A., Cantagrel, J. M., Fúster, J. M., Ibarrola, E., and Coello, J., 1994, Constructive and destructive episodes in the building of a young oceanic island, La Palma, Canary Islands, and genesis of the Caldera de Taburiente: Joumal of Volcanology and Geothermal Research,v. 60, p. 243-262.

Ancochea, E., Huertas, M. J., Fúster, J. M., Cantagrel, J. M., Coello, J., and Ibarrola, E., 1995, Geocronología de la Pared de la Caldera de las Cañadas (Tenerife, Islas Canarias): Boletín Real de la Sociedad Española de Historia Natural (Geología), v. 90, p. 107-124

Ancochea, E., Cantagrel, J. M., Fúster, J. M., Huertas, M. J., and Amaud, N. ๑., 1998, Vertical and lateral collapses on Tenerife (Canary Islands) and other volcanic ocean islands: Comment: Geology, v. 26, p. 861-862.

Ancochea, E., Huertas, M. J., Cantagrel, J. M., Coello, J., Fúster, J. M., Amaud, N., and Ibarrola, E., 1999, Evolution of the Cañadas Edifice and its implications for the origin of the Cañadas Caldera (Tenerife, Canary Islands): Joumal of Volcanology and Geothermal Research, v. 88, p. $177-199$

Bravo, T., 1962, Elcirco de Las Cañadas ysus dependencias: Boletín Real de laSociedad Española Historia Natural (Geologia), v. 60, p. 93-108.

Bryan, S., Martí, J., and Cas, R. A. F., 1998, Stratigraphy of the Bandas delSur Formation: An extracalderarec ord of Quatemary phonolitic explosive enuptions from the Las Cañadas edifice, Tenerife (Canary Islands): Geological Magazine, v. 135, p. 605-636.

Carracedo, J. C., 1994, The Canary Islands: An example of structural control on the growth of large oceanic-island volcanoes: Journal of Volcanology and Geothermal Research, v. 60, p. 225-241.

Coello, J., 1973, Las series volcánicas en subsuelos de Tenerife: Estudios Geológicos, v. 29, p. 491-512.

Fúster, J. M., Hemán, F., Cendrero, A., Coello, J., Cantagrel, J. M., Ancochea, E., and Ibarrola, E., 1993, Geocronología de la isla de El Hierro (Islas Canarias): Boletín Real de la Sociedad Española Historia Natural (Geología), v. 88, p. 85-97.

Fúster, J. M., Ibanrola, E., Snelling, N. J., Cantagrel, J. M., Huertas, M. J., Coello, J., and Ancochea, E., 1994, Cronología K-Ar de la Formación Cañadas en el sector suroeste de Tenerife: Impli- caciones de los episodios piroclásticos en la evolución volcánica: Boletín Real de laSociedad Española Historia Natural (Geología), v. 89, p. $25-41$.

Holcomb, R. T., and Searle, R. C., 1991, Large landslides from oceanic volcanoes: Marine Geotechnology, v. 10, p. 19-32.

Ibarrola, E., Ancochea, E., Fúster, J. M., Cantagrel, J. M., Coello, J., Snelling, N. J., and Huertas, M. J., 1993, Cronoestratigrafia del Macizo de Tigaiga: evolución de un sector del Edificio Cañadas (Tenerife, Islas Canarias): Boletín Real de laSociedad Española Historia Natural (Geología), v. 88, p. 57-72.

Martí, J., Mitjavila, J., and Villa, I., 1990, Stratigraphy and $\mathrm{K}$-Ar ages of the Cañada de Diego Hemánde and their significance on the Las Cañarlas caldera formation (Tenerife, Canary Islands): Terra Nova, v. 2, p. $148-153$.

Martí, J., Mitjavila, J., and Araña, V., 1994, Stratigraphy, structure and geochronology of the Las Cañadas caldera (Tenerife, Canary Islands): Geological Magazine, v. 131,p. 715-727.

Martí, J., Hurlimann, M., Ablay, G. J., and Gudnundsson, A., 1997, Vertical and lateral collapses on Tenerife (Canary Islands) and other volcanic oceanislands: Geology, v. 25, p. 879-882.

Masson, D. G., 1996, Catastrophic collapse of the volcanic island of Hierro $15 \mathrm{ka}$ ago and the history of landslides in the Canary Islands: Geology, v. 24, p. 231-234.

Mitjavila, J., and Villa, I., 1993, Temporal evolution of Diego Hemández formation (Las Cañadas, Tenerife) and confirmation of the age of the caldera using the ${ }^{4} \mathrm{Ar}-{ }^{39} \mathrm{Ar}$ method: Revista de la Sociedad Geológica España, v. 6, p. 61-65

Navarro, J. M., and Coello, J., 1989, Depressions originate by landslide processes in Tenerife: European Science Foundation Meeting on Canarian Volcanism, Cabildo insular de Lanzarote, Abstract, p. 150-152.

Teide Group, 1997, Morphometric interpretation of the northwest and southeast slopes of Tenerife, Canary Islands: Journal of Geophysical Research, v. 102, p. 20,325-20,342.

Watts, A. B., and Masson, D. G., 1995, A giant landslide on the north flank of Tenerife, Canary Islands: Journal of Geophysical Research, v. 100 , p. $24,487-24,498$.

Watts, A. B., and Masson, D. G., 1998, A giant landslide on the north flank of Tenerife, Canary Islands: Reply: Joumal of Geophysical Research, v. 103, p. 9949-9952.

Wolff, J. A., 1985, Zonation mixing and enuptions of silica-undersaturated alkaline magma: A case study from Tenerife, Canary Islands: Geological Magazine, v. 122, p. 623-640. 